\title{
Pengaruh Tingkat Pengangguran, Kebutuhan Pangan, Peningkatan Gizi, Dan Peningkatan Pendapatan Per Kapita Terhadap Kawasan Rumah Pangan Lestari (KRPL)
}

\author{
Supardi ${ }^{1}$, Nurshadrina Kartika Sari ${ }^{2}$ \\ Email: dan shadrina.kartika@gmail.com
}

Sekolah Tinggi Ilmu Ekonomi MANDALA, Jember

\begin{abstract}
This study aims to analyze the effect of unemployment rate, food demand, nutrition improvement and income increase per capita after applying Sustainable Food House (KRPL) in Jember Regency. Analysis tool used Multiple Regression Analysis is the number of independent variables used to predict variables depend on more than one. The research design used is associative design, ie to analyze the relationship between one variable with other variables or how a variable affects other variables. The writer uses case study with quantitative approach while the unit of analysis in this research is the influence of Unemployment rate, Food Needs, Nutrition Improvement, and Increase Revenue per Capita to Area Sustainable Food House (KRPL). The sampling method used is the census method, which is a comprehensive sampling of 3 villages with a 3-year study period from 2014 to 2016. Analytical techniques are multiple regression analysis, $F$ test and t test.

Keywords: unemployment, food, nutrition, income and krpl.
\end{abstract}

\section{PENDAHULUAN}

Dalam rangka optimalisasi atau memanfaatkan lahan perkarangan rumah yang sangat terbatas perlunya dikelolah menerapkan Kawasan Rumah Pangan Lestari (KRPL). KRPL adalah konsep penumbuhan dan pemanfaatan pekarangan terbatas untuk dapat mengurangi pengangguran, memenuhi kebutuhan pangan, peningkatan gizi keluarga serta dapat membatu pendapatan per kapita.

Corresponding Author:

Email :Supardiav2@gmail.com 
Tujuan utama KRPL adalah untuk dapat mengahsilkan dan dapat mengurangi pengangguran, memenuhi kebutuhan pangan, peningkatan gizi keluarga serta bisa membatu pendapatan per kapita. KRPL sebenarnya sudah lama diterapkan oleh masyarakat, dengan cara praktek-praktek menanam dalam skala terbatas (dalam pot) dan banyak jenis tanaman (keragaman tanaman) sudah lama dijalankan baik pada masyarakat pedesaan maupun perkotaan. Hanya saja pola dan sistem pengerjaannya masih dilaksanakan secara individu rumah tangga dan belum terorganisir sehingga aplikasinya belum dapat mempengaruhi tentang aspek pengangguran, memenuhi kebutuhan pangan, peningkatan gizi keluarga serta dapat membatu pendapatan per kapita.

UndangUndang Pangan Nomor 18 Tahun 2012 tentang pembangunan ketahan pangan di Indonesia sebagai pengganti Undang-Undang Pangan Nomor 7 Tahun 1996, yang dibangun berlandaskan kedaulatan dan kemandirian pangan. Hal ini menggambarkan bahwa apabila suatu negara tidak mandiri dalam pemenuhan pangan, maka kedaulatan negara bisa terancam. Pangan merupakan kebutuhan dasar manusia sehingga secara normatif sumber utama pasokan pangan harus dapat diproduksi sendiri hingga tingkat rumah tangga.

Selaras dengan hal tersebut, maka dalam pewujudan PERPRES No. 22 Tahun 2009 tentang Kebijakan Percepatan Penganekaragaman Konsumsi Pangan Berbasis Sumberdaya Lokal antara lain dapat melalui aplikasi konsep KRPL di segenap wilayah perkotaan dan pedesaan di seluruh wilayah tanah air. Pembangunan ketahanan pangan termasuk prioritas nasional dalam RPJM 20102014 yang difokuskan pada peningkatan ketersediaan pangan, pemantapan distribusi pangan, percepatan penganekaragaman pangan sesuai dengan karakteristik daerah. Implementasi program pembangunan ketahanan pangan tersebut dilaksanakan dengan memperhatikan subsistem ketahanan pangan, antara lain, mengupayakan peningkatan produksi dan ketersediaan pangan dan peningkatan kualitas konsumsi masyarakat. Konsep ketahanan pangan selalu identik dengan ukuran kemandirian pangan, yakni terpenuhinya kebutuhan pangan (nasional/kawasan) secara mandiri dengan memberdayakan modal manusia, sosial dan ekonomi (termasuk lahan pekarangan dan pertanian serta sekitarnya) yang 
dimiliki, dan berdampak kepada peningkatan kehidupan sosial dan ekonomi masyarakat dan petani. Kemandirian pangan hanya dapat terwujud jika pembangunannya dan penumbuhannya dilaksanakan atas dasar prakarsa (partisipatif aktif) masyarakatnya sendiri sebagai bentuk kesadaran untuk membangun ketahanan pangan yang andal.

Mengacu pada penjelasan tersebut di atas sangatlah tepat konsep KRPL di luncurkan, karena rumah tangga sebagai bentuk masyarakat terkecil, baik di daerah perkotaan maupun pedesaan sangatlah strategis sebagai sasaran dalam setiap upaya peningkatan kemandirian pangan hingga tingkat nasional. Dengan demikian dalam paradigm implementasinya agar dapat berjalan dengan baik dan lancar di lapangan antara lain: direncanakan dan dilakukan secara partisipatif, disosialisasikan secara informatif dan komunikatif, dan didukung secara terintegratif dan komprehensif. Program yang diterbitkan oleh Kementrian Pertanian bersama Badan Litbang pada awal tahun 2011 dalam mendukung kegiatan pemanfaatan lahan pekarangan adalah Program KRPL. Model Kawasan Rumah Pangan Lestari (Model KRPL) merupakan pemanfaatan pekarangan yang ramah lingkungan dan dirancang untuk pemenuhan kebutuhan pangan dan menambah gizi keluarga, diversifikasi pangan berbasis sumber daya lokal, pelestarian tanaman pangan untuk masa depan, serta peningkatan pendapatan yang pada akhirnya akan meningkatkan kesejahteraan masyarakat. (Litbang, 2015). Pemanfaatan pekarangan dalam konsep KRPL dilengkapi dengan kelembagaan Kebun Bibit Desa, unit pengolahan serta pemasaran. Program KRPL secara khusus dimanfaatkan sebagai salah satu media untuk pemenuhan kebutuhan pangan dan gizi keluarga dan sumber tambahan pendapatan bagi rumah tangga. Lembaga pemasaran dimaksudkan untuk menampung hasil produksi tanaman pekarangan yang telah melebihi jumlah kebutuhan konsumsi sehari-hari, kelebihan hasil produksi tanaman dapat dijadikan sebagai tambahan pendapatan bagi keluarga anggota pelaksana program KRPL dengan menjual hasil tanaman pekarangan (Litbang, 2015).

Bupati Jember Faida mengatakan, realisasi pendapatan daerah tahun anggaran 2015 mencapai 97, 17 persen dari target yang sudah ditentukan dalam APBD 2015 sebesar Rp3, 207 triliun. Realisasi pendapatan pada tahun anggaran 
2015 sebesar Rp3, 116 triliun atau naik sekitar 97, 17 persen dari target. Sedangkan pendapatan asli daerah tahun 2015 targetnya sebesar Rp508 miliar, tapi realisasinya sebesar Rp462 miliar atau sekitar 90,84 persen. Kemudian pendapatan dana perimbangan targetnya sebesar Rp1, 951 triliun dengan realisasi Rp1, 917 triliun atau persentasenya 98, 27 persen. Selanjutnya lainlain pendapatan daerah sah targetnya sebesar Rp747 miliar dengan realisasi Rp736 miliar atau 98, 60 persen.

Rincian target pendapatan asli daerah meliputi pajak daerah sebesar Rp129 miliar dengan realisasi Rp123 miliar (94, 85 persen), retribusi daerah direncanakan sebesar Rp41 miliar dengan realisasi sebesar Rp34 miliar (83,15 persen), hasil pengelolaan kekayaan daerah targetnya sebesar Rp5,14 miliar dengan realisasi Rp5,28 miliar (102,72 persen), dan lain-lain pendapatan asli daerah yang sah targetnya Rp331 miliar, tapi realisasinya Rp298 miliar (90,05 persen). Sementara untuk realisasi belanja daerah pada APBD 2015 sebesar 85 persen dari target belanja yang direncanakan sebesar Rp3,611 triliun telah direalisasikan sebesar Rp3,083 triliun. "Belanja daerah terbagi menjadi dua, yakni belanja langsung bisa direalisasikan sebesar 78,89 persen dari target Rp1,519 triliun dan belanja tidak langsung bisa direalisasikan 90,10 persen dari target $\mathrm{Rp} 2,092$ triliun. Target utama Kabupaten Jember bebas pengangguran.

Memperhatikan program Pemerintah Daerah Kabupaten Jember tersebut diatas, maka ketika survey ke Desa-desa yang berada di kawasan Kabupaten Jember, penulis menjumpai masih terdapat kawasan yang belum dioptimalkan pemanfaatan lahannya. Serta terdapat beberapa desa yang mendukung Program Pemerintah Daerah Kabupaten Jember dengan menerap Kawasan Rumah Pangan Lestari (KRPL). Dimana kehidupan masyarakat terbebas dari pengangguran, tidak kekurangan pangan, gizi dan dapat meningkatkan pendapatan rumahtangga pada Kabupaten Jember tersebut serta dapat mengurangi pengangguran.

Berdasarkan latar belakang masalah di atas, maka permasalahan dalam penelitian ini dirumuskan sebagai berikut:

1. Bagaimana pengaruh tingkat pengangguran terhadap Kawasan Rumah Pangan Lestari? 
2. Bagaimana pengaruh kebutuhan pangan terhadap Kawasan Rumah Pangan Lestari?

3. Bagaimana pengaruh peningkatan gizi terhadap Kawasan Rumah Pangan Lestari?

4. Bagaimana pengaruh peningkatan pendapatan per kapita terhadap Kawasan Rumah Pangan Lestari?

5. Bagaimana pengaruh secara simultan tingkat pengangguran, kebutuhan pangan, peningkatan gizi dan peningkatan pendapatan per kapita secara simultan terhadap Kawasan Rumah Pangan Lestari?

\section{TINJAUAN PUSTAKA}

\section{Pengangguran}

Masalah kesempatan kerja dijamin oleh UUD 1945 Pasal 27 Ayat 2 yang berbunyi tiap-tiap warga negara berhak atas pekerjaan dan penghidupan yang layak. Sehingga pemerintah Indonesia bertanggung jawab atas penciptaan kesempatan kerja dan perlindungan terhadap tenaga kerja. Masalah kesempatan kerja merupakan masalah yang serius bagi semua negara baik negara berkembang maupun negara maju. Menurut Sumitro Djojohadikusumo pembangunan ekonomi adalah usaha memperbesar pendapatan perkapita dan menaikkan produktivitas per kapita dengan jalan menambah peralatan modal dan skill.

Pengangguran adalah suatu keadaan di mana seseorang yang tergolong dalam angkatan kerja ingin mendapatkan pekerjaan tetapi belum dapat memperolehnya (Sudono Sukirno, 2008: 8). Seseorang yang tidak bekerja, tetapi tidak secara aktif mencari pekerjaan tidak tergolong sebagai penganggur. Pengangguran dapat terjadi disebabkan karena tidakseimbangan pada pasar tenaga kerja. Dimana jumlah pencari kerja melebihi jumlah tenaga kerja yang dibuhkan. Menurut Badan Pusat Statistik (BPS) dalam indikator ketenagakerjaan, pengangguran merupakan penduduk yang tidak bekerja tetapi sedang mencari pekerjaan atau sedang mempersiapkan suatu usaha baru atau penduduk yang tidak mencari pekerjaan karena sudah diterima bekerja tetapi belum mulai bekerja.

\section{Kebutuhan Pangan}

Dalam Permentan No 65 Tahun 2010 mengenai Petunjuk Teknis Standard Pelayanan Bidang Ketahanan Pangan Provinsi dan Kabupaten atau Kota, Ketahanan Pangan 
adalah kondisi terpenuhinya kebutuhan pangan bagi rumah tangga yang tercermin dari tersedianya pangan yang cukup, baik jumlah maupun mutunya, aman, merata dan terjangkau. Oleh karena terpenuhinya pangan menjadi hak asasi bagi masyarakat, melalui Undang-Undang Nomor 32 Tahun 2004 tentang Pemerintahan Daerah, dan Peraturan Pemerintah Nomor 38 Tahun 2007 tentang Pembagian Urusan Pemerintahan Antara Pemerintah, Pemerintahan Daerah Provinsi dan Pemerintahan Daerah Kabupaten atau Kota dalam Pasal 7 huruf $m$ dan Pasal 8, urusan Ketahanan Pangan merupakan urusan wajib berkaitan dengan pelayanan dasar dalam pemenuhan kebutuhan hidup minimal.

Dalam penyelenggaran ketahanan pangan, peran Pemerintahan Provinsi dan Kabupaten/Kota dalam mewujudkan ketahanan pangan sebagaimana diamanatkan dalam Pasal 13 Peraturan Pemerintah Nomor 68 Tahun 2002 adalah melaksanakan dan bertanggung jawab terhadap penyelenggaraan ketahanan pangan di wilayah masing-masing dan mendorong keikutsertaan masyarakat dalam penyelenggaraan ketahanan pangan, dilakukan dengan : (a) Memberikan informasi dan pendidikan ketahanan pangan (b) Meningkatkan motivasi masyarakat (c) Membantu kelancaran penyelenggaraan ketahanan pangan (d) Meningkatkan kemandirian ketahanan pangan. Menurut Nuhfil (2005), ketahanan pangan dengan prinsip kemandirian dan berkelanjutan senantiasa harus diwujudkan dari waktu ke waktu, sebagai prasyarat bagi keberlanjutan eksistensi bangsa Indonesia. Upaya mewujudkan ketahanan pangan tidak terlepas dari pengaruh faktor-faktor internal maupun eksternal yang terus berubah secara dinamis. Dinamika dan kompleksitas ketahanan pangan menimbulkan berbagai permasalahan dan tantangan serta potensi dan peluang yang terus berkembang yang perlu diantisipasi dan diatasi melalui kerjasama yang harmonis antar seluruh pihak terkait dalam mewujudkan ketahanan pangan. Dalam PPRI No. 68 Tahun 2002, untuk memenuhi penyediaan dalam rangka pemenuhan kebutuhan konsumsi rumah tangga yang terus berkembang dilakukan dengan : a. mengembangkan sistem produksi pangan yang bertumpu pada sumberdaya, kelembagaan dan budaya lokal; b. mengembangkan efisiensi sistem usaha pangan; c. mengembangkan teknologi produksi pangan; d. mengembangkan sarana dan prasarana produksi pangan

\section{Peningkatan Gizi}

Untuk mencapai keadaan gizi yang baik, maka unsur kualitas dan kuantitas harus dapat terpenuhi. Apabila tubuh kekurangan zat gizi, khususnya energi dan 
protein, pada tahap awal akan meyebabkan rasa lapar dan dalam jangka waktu tertentu berat badan akan menurun yang disertai dengan menurunnya produktivitas kerja. Kekurangan zat gizi yang berlanjut akan menyebabkan status gizi kurang dan gizi buruk. Apabila tidak ada perbaikan konsumsi energi dan protein yang mencukupi, pada akhirnya tubuh akan mudah terserang penyakit infeksi yang selanjutnya dapat menyebabkan kematian.

Kerawanan atau kecukupan pangan gizi dapat diukur dari prosentase Angka Kecukupan Gizi yang terdiri dari prosentase Angka Kecukupan Gizi terhadap Energi (AKE), prosentase Angka Kecukupan Gizi terhadap Protein (AKP), prosentase Angka Kecukupan Gizi terhadap lemak (AKL) dan Angka Kecukupan Gizi terhadap unsur-unsur mikro (AKMikro). Prosentase AKE merupakan pembagian dari AKE aktual dibagi dengan AKE normative dikali 100, sedangkan prosentase AKP merupakan pembagian dari AKP aktual dibagi AKP normatif dikali 100. Dikatakan rawan gizi apabila prosentase AKE dan AKP kurang dari $75 \%$. AKG normatif diperoleh dari Widyakarya Pangan dan Gizi tahun 2004, angka tersebut direkomendasikan agar seseorang dapat hidup sehat dan dapat aktif menjalankan aktifitas sehari-hari secara produktif. Karena di dalam makanan terkandung zat gizi (karbohidrat, lemak dan protein) untuk memenuhi trifungsi makanan yaitu sebagai penghasil energi, untuk pembangun/pertumbuhan dan untuk pengatur/pemelihara. Sedangkan untuk AKL, angka lemak aktual dihitung $15 \%$ dari energi yang diserap oleh responden, kemudian AKL aktual dibagi dengan AKL normatif (dengan melihat lampiran AKG normatif). Selain Energi, Lemak dan Protein yang akan dihitung, untuk lebih mengetahui Angka Kecukupan Gizi lebih lengkap agar hasil penelitian ini dapat digunakan untuk strategi ketahanan pangan, maka dihitung pula Angka Kecukupan Gizi terhadap unsur mikro seperti Calsium, Zat besi, vitamin C dan Fosfor. Perhitungan Angka Kecukupan Gizi Mikro kemudian dibandingkan dengan anjuran dari Model Pengukuran oleh hasil Widyakarya Pangan tahun 2004 (lampiran).

\section{Peningkatan Pendapatan per Kapita}

Manajemen pemerintah daerah di Indonesia memasuki era baru seiring dengan diberlakukannya desentralisasi fiskal. Kebijakan terkait yang tertuang dalam UU No. 22 tahun 1999 tentang Pemerintahan Daerah dan UU No 25 tahun 1999 tentang Perimbangan Keuangan antara Pemerintah Pusat dan Daerah efektif diberlakukan per Januari tahun 2001 
(UU ini dalam perkembangannya diperbarui dengan dikeluarkannya UU No.32 tahun 2004 dan UU No. 33 tahun 2004). Diberlakukannya undang-undang ini memberikan peluang bagi daerah untuk menggali potensi lokal dan meningkatkan kinerja keuangannya dalam rangka mewujudkan kemandirian daerah. Dalam era desentralisasi fiskal diharapkan terjadinya peningkatan pelayanan diberbagai sektor terutama sektor publik. Peningkatan layanan publik ini diharapkan dapat meningkatkan daya tarik bagi investor untuk membuka usaha di daerah. Harapan ini tentu saja dapat terwujud apabila ada upaya serius (pemerintah) dengan memberikan berbagai fasilitas pendukung (investasi). Konsekuensinya, pemerintah perlu untuk memberikan alokasi belanja yang lebih besar untuk tujuan ini. Desentralisasi fiskal disatu sisi memberikan kewenangan yang lebih besar dalam pengelolaan daerah, tetapi disisi lain memunculkan persoalan baru, dikarenakan tingkat kesiapan fiskal daerah yang berbedabeda. Penelitian yang dilakukan Adi (2005) menunjukkan terjadi disparitas pertumbuhan ekonomi yang cukup tinggi antar daerah (kabupaten dan kota) dalam pelaksanaan desentralisasi fiskal. Nanga (2005) mengindikasikan terjadinya ketimpangan fiskal antar daerah dan bisa jadi hal ini mempengaruhi tingkat pertumbuhan ekonomi daerah. Pendapatan per kapita adalah pendapatan rata-rata penduduk suatu negara (Untoro, 2010: 13). Pendapatan perkapita menunjukan tingkat pendapatan masyarakat dalam suatu negara. Variable yang digunakan untuk menghitung pendapatan per kapita adalah produk nasional bruto dan jumlah penduduk. Secara matematis, rumus perhitungan pendapatan per kapita adalah sebagai berikut: Pendapatan per kapita $=$ Produk Nasional Bruto (GNP) atau Jumlah Penduduk. Menurut Rakiman (2011: 80) Pendapatan Perkapita suatu negara merupaka tolak ukur kemajuan dari negara tersebut, apabila pendapatan perkapita suatu negara rendah dapat dipastikan mekanisme ekonomi masyarakat di negara tersebut mengalami penurunan, dan begitu pula sebaliknya apabila pendapatan perkapita suatu negara tinggi maka dapat dipastikan mekanisme ekonomi masyarakat tersebut mengalami peningkatan, tapi pendapatan tersebut bukan hanya didapat atau diperoleh dari mekanisme ekonomi masyarakatnya saja, banyak faktor yang mempengaruhi penurunan atau peningkatan pendapatan tersebut seperti keadaan alam yang tidak dapat diperkirakan keadaannya, kondisi alam ini dapat berubah sewaktu-waktu yang dapat menimbulkan bencana alam yang akan membuat pendapatan suatu negara akan mengalami penurunan. Hal ini berlaku bagi seluruh negara di belahan dunia tidak terkecuali di negara Indonesia. 


\section{Kawasan Rumah Pangan Lestari (KRPL)}

Berdasarkan Pedoman Umum P2KP (2009) menyatakan bahwa KRPL merupakan salah satu budaya bangsa yang berharga, yaitu memanfaatkan pekarangan sebagai sumber bahan pangan keluarga melalui penanaman berbagai tanaman sayuran, buah-buahan, umbi-umbian dan tanaman obat serta pemeliharaan ternak. Demi memberikan dampak yang lebih luas dalam rangka kemandirian pangan, maka konsep Rumah Pangan (RP) tersebut kemudian secara kreatif dan kritis dikembangkan menjadi konsep Kawasan Rumah Pangan Lestari (KRPL).

Kementerian Pertanian saat ini (tahun 2011) sedang menggalakkan usaha tani di lahan pekarangan yang dikenal dengan pengembangan Kawasan Rumah Pangan Lestari (KRPL). Menurut Subagyono (2011) Penambahan kata "kawasan" dibagian depan dimaksudkan untuk menunjukkan bahwa tujuan dari program ini tidak hanya sekedar rumah per rumah melainkan dikembangkan dalam skala lebih luas. Berbeda dengan Rumah Pangan (RP) yang dilaksanakan rumah per rumah secara sendiri-sendiri tanpa ada keterkaitan dengan yang lain, KRPL diharapkan dapat melibatkan banyak rumah tangga dan saling terkait yaitu berbasis Rukun Tetangga/Rukun Warga (RT/RW), dusun (kampung), desa, atau wilayah lain yang memungkinkan. Dalam hal ini, partisipasi aktif masyarakat adalah suatu keharusan. Posisi pemerintah dalam program ini hanyalah sebagai penggerak awal dan pendamping yang ikut membimbing dan mendukung terbentuknya KRPL. Dengan kata lain, KRPL ini harus direncanakan dan dilaksanakan secara partisipatif (dari masyarakat, oleh masyarakat dan untuk masyarakat) serta kemudian dievaluasi dan disempurnakan secara kreatif dan kritis oleh masyarakat dan pemerintah melalui aparat penggerak/penyuluh di lapangan. Tujuan dari KRPL berdasarkan petunjuk pelaksanaan kegiatan P2KP (2013) adalah: 1. Memenuhi kebutuhan pangan dan gizi keluarga dan masyarakat melalui optimalisasi pemanfaatan pekarangan secara lestari. 2. Meningkatkan kemampuan keluarga dan masyarakat dalam pemanfaatan pekarangan di perkotaan maupun perdesaan untuk budidaya tanaman pangan, buah, sayuran dan tanaman obat keluarga (toga), pemeliharaan ternak dan ikan, serta diversifikasi pangan. 3. Mengembangkan sumber benih/bibit untuk menjaga keberlanjutan pemanfaatan pekarangan dan melakukan pelestarian tanaman pangan lokal untuk masa depan. 4. Mengembangkan kegiatan ekonomi produktif keluarga sehingga mampu 
meningkatkan kesejahteraan keluarga dan menciptakan lingkungan hijau yang bersih dan sehat secara mandiri.

\section{Kajian Penelitian Sebelumnya}

Pembahasan hasil penelitian terdahulu dimaksudkan agar dapat memberikan gambaran untuk memperjelas kerangka berpikir penelitian ini. Disamping itu juga merupakan referensi yang akan digunakan dalam melakukan evaluasi terhadap pengaruh masing-masing konsep. Penelitian yang dilakukan oleh Zahro (2012) yang berjudul Kontribusi Pengembangan Kawasan Rumah Pangan Lestari Dalam Mendukung Kesejahteraan Masyarakat. Studi Kasus pengaruh tingkat Pengangguran, Kebutuhan Pangan, Peningkatan Gizi, dan Peningkatan Pendapatan per Kapita terhadap Kawasan Rumah Pangan Lestari (KRPL) memiliki persamaan variabel yang dikaji dalam penelitian ini yaitu mengenai persepsi terhadap KRPL serta manfaat dalam memenuhi kebutuhan pangan keluarga dan pendapatan keluarga. Adapun perbedaannya terletak pada tingkat pengangguran dan peningkatan gizi terhadap pengaruh KRPL. Hasil penelitian menunjukkan bahwa adanya peningkatan pemanfaat lahan, mengurangi pengangguran, Kebutuhan Pangan, Peningkatan Gizi, dan Peningkatan Pendapatan per Kapita.

Penelitian yang dilakukan oleh Aji (2013) berjudul Dampak Program Kawasan Rumah Pangan Lestari (KRPL) Terhadap Pengeluaran Konsumsi Rumah Tangga 19 (Studi Kasus Di Desa Pucangsari Kecamatan Purwodadi Kabupaten Pasuruan) juga memiliki persamaan kajian dalam penelitian ini, yaitu dampak program KRPL terhadap pengeluaran rumah tangga. Adapun perbedaannya terletak pada variabel yang mempengaruhi yaitu karakteristik wanita tani dan pelaksanaan program. Sedangkan penelitian ini menunjukkan bahwa pengaruh tingkat pengangguran, Kebutuhan Pangan, Peningkatan Gizi, dan Peningkatan Pendapatan per Kapita. Penelitian yang dilakukan oleh Udayani (2010) berjudul Dampak BLMUP3HP Terhadap Peningkatan Pendapatan dan Penyerapan Tenaga Kerja pada KWT di Kabupaten Klungkung memiliki persamaan kajian dalam penelitian ini, yaitu tujuan penelitian dalam melihat menganalisis keberhasilan suatu program. Adapun perbedaannya terletak pada variabel yang dianalisis. Hasil penelitian menunjukkan bahwa dana BLM-UP3HP berdampak positif terhadap peningkatan pendapatan KWT dan penyerapan tenaga kerja pada KWT di Kabupaten Klungkung. Sedangkan penelitian ini 
adalah pengaruh tingkat pengangguran, Kebutuhan Pangan, Peningkatan Gizi, dan Peningkatan Pendapatan per Kapita. Penelitian yang dilakukan oleh Prasetyowati (2014) berjudul Peranan Wanita Tani dalam Penerapan Teknologi Pengelolaan Tanaman Terpadu (PTT) pada usahatani jagung di Kecamatan Pringgabaya Kabupaten Lombok Timur Adapun perbedaannya terletak pada variabel yang dianalisis. Hasil penelitian menunjukkan bahwa wanita tani cukup berperan dalam penerapan teknologi PTT jagung, terutama dalam hal penerapan komponen varietas unggul, benih bermutu, populasi tanam, pemupukan dan pengendalian hama penyakit. Sedangkan penelitian ini adalah pengaruh tingkat pengangguran, Kebutuhan Pangan, Peningkatan Gizi, dan Peningkatan Pendapatan per Kapita.

\section{Hipotesis}

Mengacu pada kerangka berpikir diatas, maka rumusan hipotesis penelitian ini adalah sebagai berikut:

H1 : diduga tingkat pengangguran dapat berpengaruh signifikan terhadap Kawasan Rumah Pangan Lestari (KRPL).

$\mathrm{H} 2$ : diduga Kebutuhan pangan dapat berpengaruh signifikan terhadap Kawasan Rumah Pangan Lestari (KRPL).

H3 : diduga peningkatan gizi dapat berpengaruh signifikan terhadap Kawasan Rumah Pangan Lestari (KRPL).

H4 : diduga peningkatan pendapatan per kapita dapat berpengaruh signifikan terhadap Kawasan Rumah Pangan Lestari (KRPL).

H5 : diduga tingkat pengangguran, kebutuhan pangan, peningkatan gizi dan peningkatan pendapatan per kapita berpengaruh secara simultan terhadap Kawasan Rumah Pangan Lestari (KRPL).

\section{METODE PENELITIAN}

\section{Metode Analisis}

Analisis Pengaruh tingkat pengangguran, kebutuhan pangan, peningkatan gizi, dan peningkatan pendapatan per kapita terhadap Kawasan Rumah Pangan Lestari (KRPL). Responden dalam penelitian ini terdiri dari tingkat pengangguran, kebutuhan pangan, peningkatan gizi, dan peningkatan pendapatan per kapita pada 
masyarakat Jember. Pengambilan sampel responden dilakukan dengan pengisian kuesioner.

\section{Populasi dan Sampel}

Populasi

Populasi dalam penelitian ini adalah menggalakkan usahatani di lahan pekarangan yang dikenal dengan pengembangan Kawasan Rumah Pangan Lestari (KRPL). Pengembangan usaha tani tersebut menggunakan pendekatan 6 konsep, yaitu: (1) Kemandirian pangan rumah tangga pada suatu kawasan, (2) Diversifikasi pangan yang berbasis sumber daya lokal, (3) Konservasi tanaman-tanaman pangan maupun pakan termasuk perkebunan, hortikultura untuk masa yang akan datang, (4) Kesejahteraan petani dan masyarakat yang memanfaatkan Kawasan Rumah Pangan Lestari, (5) Pemanfaatan kebun bibit desa agar menjamin kebutuhan masyarakat akan bibit terpenuhi, baik bibit tanaman pangan, hortikultura, perkebunan, termasuk ternak, unggas, ikan dan lainnya, (6) Antisipasi dampak perubahan iklim

Sampel

Penelitian ini mengambil sampel pada pengaruh tingkat Pengangguran, Kebutuhan Pangan, Peningkatan Gizi, dan Peningkatan Pendapatan per Kapita dengan menggunakan system time series selama 5 tahun yaitu tahun 2012 sampai dengan tahun 2016, yang diperoleh sebanyak 60.

\section{Rancangan Penelitian}

Desain penelitian yang digunakan adalah desain asosiatif, yaitu untuk menganalisis hubungan antara satu variabel dengan variabel lainnya atau bagaimana suatu variabel mempengaruhi variabel lain. Penulis menggunakan studi kasus dengan pendekatan kuantitatif sedangkan unit analisis dalam penelitian ini adalah pengaruh tingkat Pengangguran, Kebutuhan Pangan, Peningkatan Gizi, dan Peningkatan Pendapatan per Kapita terhadap Kawasan Rumah Pangan Lestari (KRPL). 


\section{Variabel Penelitian}

1. Variabel Independen

Variabel independen dalam penelitian ini adalah pengaruh tingkat Pengangguran (X1), Kebutuhan Pangan (X2), Peningkatan Gizi (X3), Peningkatan Pendapatan per Kapita (X4).

2. Variabel Dependen

Variabel Dependen (terikat) dalam penelitian ini adalah Kawasan Rumah Pangan Lestari (KRPL) (Y).

\section{Teknik Analisis Data}

\section{Analisis Regresi Linear Berganda}

Analisis Regresi Berganda adalah jumlah variabel bebas yang digunakan untuk memprediksi variabel tergantung lebih dari satu. Dalam hal ini yang menjadi variabel bebas adalah pengaruh tingkat Pengangguran, Kebutuhan Pangan, Peningkatan Gizi, dan Peningkatan Pendapatan per Kapita sedangkan variabel terikat adalah Kawasan Rumah Pangan Lestari (KRPL). Secara umum dapat ditulis sebagai berikut:

Model Statistik

$$
Y=\alpha_{0}+\alpha_{1} X_{1}+\alpha_{2} X_{2}+\alpha_{3} X_{3}+\alpha_{4} X_{4}+\alpha_{5} X_{5}+e
$$

Keterangan:

$\mathrm{Y} \quad=$ Kawasan Rumah Pangan Lestari (KRPL)

$\alpha_{0}, \beta_{0}=$ Konstanta atau intersep

$\alpha_{1} \ldots \alpha_{4}=$ Koefisien regresi

$\mathrm{X}_{1} \quad=$ pengaruh tingkat Pengangguran

$\mathrm{X}_{2}=$ Kebutuhan Pangan

$\mathrm{X}_{3} \quad=$ Peningkatan Gizi

$\mathrm{X}_{4} \quad=$ Peningkatan Pendapatan per Kapita

X5 = pengaruh secara simultan tingkat pengangguran, kebutuhan pangan, peningkatan gizi dan pendapatan per kapita

$\mathrm{e}=$ error term 


\section{PEMBAHASAN}

Analisis data ini menggunakan analisis regresi berganda untuk mengetahui seberapa besar pengaruh tingkat pengangguran, kebutuhan pangan, peningkatan gizi, dan peningkatan pendapatan per kapita terhadap kawasan rumah pangan lestari. Berdasarkan output SPSS (Statistical Product and Service Solutions) versi 17 for windows, dimana ringkasan hasil analisis data disajikan pada tabel 2 di bawah ini.

Tabel 2. Hasil Analisis Regresi Linier Berganda

\begin{tabular}{lcccc}
\hline \multicolumn{1}{c}{ Variabel } & $\begin{array}{c}\text { Koefisien } \\
\text { Regresi }\end{array}$ & $\begin{array}{c}\text { Standard } \\
\text { error }\end{array}$ & Nilai t & Nilai p \\
\hline Tingkat Pengangguran & 0,583 & 0,128 & 4,569 & $0,000^{*}$ \\
Kebutuhan Pangan & 0,750 & 0,351 & 2,139 & $0,037^{*}$ \\
$\begin{array}{l}\text { Peningkatan Gizi } \\
\text { Peningkatan Pendapatan per }\end{array}$ & 1,588 & 0,355 & 4,478 & $0,000^{*}$ \\
Kapita & 0,327 & 0,150 & 2,184 & $0,033^{*}$ \\
\hline F & & & &
\end{tabular}

Sig F : 0,000

Adjusted R Square : 0,638

*) secara statistik signifikan pada level $\alpha=5 \%$.

Berdasarkan Tabel 2 dapat diketahui bahwa pengaruh tingkat pengangguran terhadap kawasan rumah pangan lestari adalah signifikan, dengan koefisien regresi 0,583 dan standard error sebesar 0,128 serta nilai t sebesar 4,569 dan nilai p sebesar 0,000. Artinya tingkat pengangguran berpengaruh signifikan terhadap kawasan rumah pangan lestari, yang berarti peningkatan tingkat pengangguran akan diikuti dengan peningkatan kawasan rumah pangan lestari. Dengan demikian hipotesis pertama secara statistik teruji.

Pengaruh kebutuhan pangan terhadap kawasan rumah pangan lestari adalah signifikan pada level $\alpha=5 \%$, dengan koefisien regresi 0,750 dan standard error sebesar 0,351 serta nilai t sebesar 2,139 dan nilai p sebesar 0,037. Artinya kebutuhan pangan berpengaruh signifikan terhadap kawasan rumah pangan lestari, 
yang berarti peningkatan kebutuhan pangan akan diikuti dengan peningkatan kawasan rumah pangan lestari. Dengan demikian hipotesis kedua secara statistik teruji.

Pengaruh peningkatan gizi terhadap kawasan rumah pangan lestari adalah signifikan pada level $\alpha=5 \%$, dengan koefisien regresi 1,588 dan standard error sebesar 0,355 serta nilai t sebesar 4,478 dan nilai $\mathrm{p}$ sebesar 0,000. Artinya peningkatan gizi berpengaruh signifikan terhadap kawasan rumah pangan lestari, yang berarti peningkatan peningkatan gizi akan diikuti dengan peningkatan kawasan rumah pangan lestari. Dengan demikian hipotesis ketiga secara statistik teruji.

Pengaruh peningkatan pendapatan per kapita terhadap kawasan rumah pangan lestari adalah signifikan pada level $\alpha=5 \%$, dengan koefisien regresi 0,327 dan standard error sebesar 0,150 serta nilai t sebesar 2,184 dan nilai p sebesar 0,033. Artinya peningkatan pendapatan per kapita berpengaruh signifikan terhadap kawasan rumah pangan lestari, yang berarti peningkatan peningkatan pendapatan per kapita akan diikuti dengan peningkatan kawasan rumah pangan lestari. Dengan demikian hipotesis keempat secara statistik teruji.

Dari hasil analisis regresi linier berganda, dapat diketahui bahwa nilai koefisien determinasi (adjusted R square) sebesar 0,638. Angka ini menunjukkan bahwa variabel tingkat pengangguran, kebutuhan pangan, peningkatan gizi, dan peningkatan pendapatan per kapita dapat menjelaskan variasi atau mampu memberikan kontribusi terhadap variabel kawasan rumah pangan lestari sebesar $63,8 \%$, sedangkan sisanya sebesar $36,2 \%$ disebabkan oleh variabel lain yang tidak dimasukkan dalam penelitian.

Dari hasil perhitungan diperoleh nilai F sebesar 27,037 dan nilai probabilitas lebih kecil dari $\alpha=0,05(0,000<0,05)$, yang berarti bahwa tingkat pengangguran, kebutuhan pangan, peningkatan gizi, dan peningkatan pendapatan per kapita secara simultan atau bersama-sama berpengaruh signifikan terhadap kawasan rumah pangan lestari. Dengan demikian hipotesis kelima secara statistik teruji.

Berdasarkan Tabel 2 dapat diketahui bahwa nilai koefisien regresi terbesar yaitu peningkatan gizi sebesar 1,588 , hal ini berarti peningkatan gizi merupakan 
variabel yang berpengaruh dominan terhadap kawasan rumah pangan lestari dibandingkan tingkat pengangguran, kebutuhan pangan dan peningkatan pendapatan per kapita.

Tingkat pengangguran berpengaruh signifikan terhadap kawasan rumah pangan lestari, yang berarti bahwa peningkatan tingkat pengganguran akan berdampak pada peningkatan kawasan rumah pangan lestari. Untuk mengurangi tingkat penggaruran dengan memanfaatkan lahan pekarangan rumah. Jadi, ini merupakan terobosan dalam menghadapi perubahan iklim melalui pemanfaatan pekarangan dalam mendukung ketersediaan serta diversifikasi pangan. Seberapapun lahan pekarangan yang ada, bisa untuk menghasilkan pangan dari rumah, karena untuk warga yang memiliki lahan terbatas bisa tetap menanam dengan teknik vertikultur. Pekarangan mempunyai peluang untuk dikembangkan sehingga secara optimal dapat menopang kehidupan masyarakat. Pada pengembangan potensi pekarangan perlu adanya program yang terencana. Program yang terencana dalam pemanfaatan pekarangan bertujuan untuk memberikan manfaat bagi pengelola yang melaksanakan kegiatan tersebut. Pekarangan sebagai salah satu praktek sederhana, sangat dekat dengan kegiatan masyarakat sehari-hari dan dimanfaatkan oleh pemerintah untuk mengadakan TOGA atau dikenal dengan apotik hidup serta sebagai penyediaan bahan pangan rumah tangga.

Kebutuhan pangan berpengaruh signifikan terhadap kawasan rumah pangan lestari, yang berarti bahwa semakin banyak kebutuhan pangan dapat meningkatkan kawasan rumah pangan lestari. Program kawasan rumah lestari, merupakan penguatan pangan bagi masyarakat yang berprofesi sebagai petani yang mempunyai lahan terbatas atau kecil, buruh tani yang tidak mempunyai lahan hanya di bayar oleh pemilik lahan, masyarakat miskin yang berprofesi sebagai buruh serabutan ataupun yang tidak mampu yang memiliki lahan di sekitar rumahnya selama ini petani dan masyarakat yang miskin tidak dapat memenuhi kebutuhan pangannya sehari-hari karena mereka menunggu penghasilan yang kecil. Sementara bagi mereka yang tidak mempunyai lahan di sekitar rumah program kawasan rumah lestari pangan juga mempunyai program pengolahan pangan, dimana masyarakat dapat meningkatkan ekonomi nya dengan belajar membuat olahan pangan. 
Peningkatan gizi berpengaruh signifikan terhadap kawasan rumah pangan lestari, yang berarti peningkatan gizi berdampak pada peningkatan kawasan rumah pangan lestari. Kegiatan kawasan rumah pangan lestari ini meliputi penanaman sayuran. Kegiatan ini dilakukan di samping untuk mengoptimalkan peran serta masyarakat juga bisa meningkatkan gizi keluarga khususnya untuk sayuran sebagai sumber vitamin dan mineral serta menunjang ekonomi keluarga karena menghemat pengeluaran keluarga untuk membeli bahan sayuran, dan untuk pengembangannya hasilnya juga bisa dijual karena ada beberapa komoditas sayuran yang tidak memerlukan lahan yang luas untuk membudidayakannya.

Peningkatan pendapatan per kapita terhadap kawasan rumah pangan lestari, yang berarti bahwa peningkatan pendapatan per kapita dapat meningkatkan kawasan rmah pangan lestari. Pendapatan perkapita merupakan salah satu ukuran kemakmuran bagi tiap daerah. Semakin tinggi pendapatan tersebut maka semakin tinggi daya beli penduduk, dan daya beli yang bertambah ini akan meningkatkan kesejahteraan masyarakat (Sukirno, 2006).

\section{KESIMPULAN}

Berdasarkan hasil analisis menunjukkan bahwa tingkat pengangguran berpengaruh signifikan terhadap Kawasan Rumah Pangan Lestari (KRPL). Kebutuhan pangan berpengaruh signifikan terhadap Kawasan Rumah Pangan Lestari (KRPL). Peningkatan gizi berpengaruh signifikan terhadap Kawasan Rumah Pangan Lestari (KRPL). Peningkatan penan per kapita berpengaruh signifikan terhadap Kawasan Rumah Pangan Lestari (KRPL). tingkat pengangguran, kebutuhan pangan, peningkatan gizi dan peningkatan penan per kapita berpengaruh secara simultan terhadap Kawasan Rumah Pangan Lestari (KRPL). Hal ini menunjukkan bahwa Kawasan Rumah Pangan Lestari (KRPL) berperan dalam tersedianya sumber pangan dan gizi keluarga yang diperoleh dari pemanfaatan pekarangan, meringankan biaya kebutuhan rumah tangga dalam penyediaan bahan pangan lokal, dan menumbuhkan produktivitas sumber daya manusia.

Penelitian ini telah diusahakan dan dilaksanakan sesuai dengan prosedur ilmiah, namun demikian masih memiliki keterbatasan yaitu: 
1. Faktor-faktor yang mempengaruhi Perilaku Etis Pelaksana dalam penelitian ini hanya terdiri dari tiga variabel, yaitu Pengendalian Intern, Kepatuhan dan Kompensasi Manajemen, sedangkan masih banyak faktor lain yang mempengaruhi Perilaku Penerapan KRPL.

2. Adanya keterbatasan penelitian dengan menggunakan kuesioner yaitu terkadang jawaban yang diberikan oleh sampel tidak menunjukkan keadaan sesungguhnya.

Tetap menjaga kawasan rumah pangan lestari yang menjadi tanggung jawab masing-masing petani sehingga menjadi kawasan rumah pangan lestari yang produktif, yang dapat memenuhi kebutuhan pangannya sendiri serta jika memungkinkan hasil yang berlebih dapat memiliki nilai ekonomis yang mampu menambah penghasilan.

\section{DAFTAR PUSTAKA}

Almatsier, 2001. Prinsip Dasar Ilmu Gizi. Pustaka Utama. Jakarta Gramedia.

Almatsier, S, 2005. Prinsip Dasar Ilmu Gizi PT. Gramedia Pustaka Utama Jakarta Arikunto, Suharsimi. 2006. Prosedur Penelitian Suatu Pendekatan Praktek. Jakarta: Rieka Cipta.

Halim, Abdul. 2004. Akuntansi Sektor Publik; Akuntansi Keuangan Daerah. Jakarta: Salemba Empat.

Mulyadi, Mohammad. 2011. Partisipasi Masyarakat dalam Pembangunan Masyarakat Desa. Nadi Pustaka. Jakarta.

Republik Indonesia. 2004. Undang-Undang Republik Indonesia Nomor 32 Tahun 2004 tentang Pemerintahan Daerah.

Republik Indonesia, 1945. Undang-Undang Dasar 1945 Pasal 27 Ayat 2. Tiap-tiap warga negara berhak atas pekerjaan dan penghidupan yang layak.

Santoso, S dan Anne Lies Ranti, 2004. Kesehatan dan Gizi. Penerbit Rineka Cipta. Jakarta.

Soemarmo, Purnomo, M. 2015. "Partisipasi Masyarakat Dalam Pengelolaan Lingkungan Hidup di Desa Mojokrapak, Kecamatan Tembelang, Jombang”. 
Juliawati, Ebit, dkk. 2012. Pengaruh Pendapatan Asli Daerah (PAD) dan Dana Perimbangan terhadap Kinerja Keuangan Pemerintah Kabupaten/Kota di Provinsi Aceh. Jurnal akuntansi Pascasarjana Universitas Syiah Kuala.

Yayasan Mitra Husada 2003, Hubungan Antara Pendapatan Keluarga dan Pola Makan. Jakarta.

Yayuk.F, Ali Khomsan, C. Meti Dwiriani, 2004 Pangan dan Gizi Penebar Swadaya.

Wiendarti I.W. dan Gunawan. 2012. Petunjuk Teknis Pengembangan Kawasan Rumah Pangan Lestari Kota Yogyakarta. BPTP Yogyakarta, BBP2TP, Badan Litbang Pertanian, Kementerian Pertanian.

Word Health Organization, 2000 Rencana Aksi Pangan dan Gizi Nasional. 